\title{
Sistem Tes Interaktif Berbasis Computerized Adaptive Testing (CAT)
}

\author{
Sanatang ${ }^{1}$, Muhammad Fajar B ${ }^{2}$ \\ ${ }^{1}$ Fakultas Teknik Universitas Negeri Makassar \\ ${ }^{2}$ ICT Universitas Negeri Makassar \\ 1sanatang.unmegmail.com \\ 2muhammadfajarbegmail.com
}

\begin{abstract}
Abstrak - Penelitian bertujuan untuk membuat sistem tes interaktif berbasis computerized adaptive testing (CAT). Penelitian ini merupakan jenis penelitian pengembangan perangkat lunak (software development) dengan menggunakan metode SDLC (Systems Development Life Cycle) dan menggunakan model Waterfall. Hasil dari penelitian ini adalah sebuah sistem tes interaktif berbasis computerized adaptive testing (CAT) yang dapat digunakan pada lembaga Testing Centre untuk mengefektifkan dan mengefisienkan kinerja lembaga Testing Centre dalam pelaksanaan tes adaptif berbasis komputer. Tanggapan responden admin terhadap aspek kemudahan administrasi/pengelolaan sistem memberikan hasil rata-rata dengan persentase 95\% sehingga termasuk kategori sangat baik, dan tanggapan responden testee terhadap aspek user friendly sistem meberikan hasil rata-rata dengan persentase $89 \%$ sehingga termasuk dalam kategori sangat baik. Sistem adaptive testing yang dibangun mampu mengukur tingkat kemampuan peserta dengan berdasar pada teori respon butir dua parameter logistik.
\end{abstract}

Kata kunci: Computerized Adaptive Testing, CAT, Sistem Tes

\section{PENDAHULUAN}

Perkembangan teknologi saat ini sudah semakin pesat dilihat dari berbagai bidang. Bidang komputer berkembang sangat cepat pada aspek kehidupan manusia, di mana pengolahan data secara manual perlahan-lahan mulai ditinggalkan dan beralih pada sistem komputer. Era industri 4.0 berkembang sangat pesat yang mencakup perangkat konektivitas atau jaringan dalam mendapatkan serta mengolah data, perangkat jaringan otomatis, Internet of Thing (IoT), big data, komputasi awan, kecerdasan buatan (Artificial Intelligence), machine learning, serta sistem keamanan siber.

Perkembangan teknologi komputer juga membawa pengaruh yang cukup besar bagi perkembangan dalam bidang pendidikan. Salah satunya yaitu memberikan kemudahan dalam bidang tes. Adanya kehadiran sistem ujian berbasis komputer atau sering dikenal dengan istilah Computer-Based Testing (CBT) dapat dijadikan sebagai solusi untuk melakukan asesmen secara digital.

Pada jenis tes CBT, setiap peserta mengerjakan sejumlah butir soal tertentu dengan jumlah butir soal adalah tetap. Penyelenggaraan tes yang memberikan sejumlah butir soal yang sama pada setiap peserta tes (testee) dengan CBT dinilai kurang efisien, khususnya untuk testee dengan kemampuan rendah dan tinggi (Lord, 1980; Hambleton, Swaminathan, \& Rogers, 1991) dalam Santoso (2010). Hal ini disebabkan karena beberapa butir soal tidak mampu memberikan informasi dalam membedakan testee dalam rentang kemampuan tertentu. Testee yang memiliki kemampuan tinggi mendapat beberapa butir soal yang mudah, di mana mereka memiliki peluang yang kecil menjawab salah. Dengan demikian, butir soal seperti itu tidak menyediakan informasi tentang kemampuan mereka. Sebaliknya, testee dengan kemampuan rendah akan mendapatkan beberapa butir soal yang sukar, di mana mereka memiliki peluang yang kecil untuk menjawab butir soal dengan benar. Akibatnya, jawaban yang salah hanya memberikan sedikit informasi mengenai kemampuan mereka. Pemberian sejumlah butir soal yang sama kepada testee juga mengakibatkan tes tidak efektif, hal ini karena tes yang memberikan butir soal yang sama mengabaikan keragaman kemampuan testee, padahal sesungguhnya kemampuan peserta tes beragam.

Sejak tahun 1980-an, di Amerika mulai dikembangkan sistem pengujian menggunakan komputer berdasarkan rancangan adaptive test yang popular disebut Computerized Adaptive Testing
(CAT). Tidak seperti pada CBT, di mana komputer hanya dimanfaatkan untuk memindahkan tes dari form kertas ke monitor komputer. Pada CAT, komputer diatur dan dimanfaatkan sedemikian hingga dapat menampilkan butir-butir soal yang sesuai dengan kemampuan individu peserta tes, karena tes disesuaikan dengan kemampuan peserta tes maka tidak ada pertanyaan yang lebih sukar ataupun lebih mudah. Peserta yang berkemampuan tinggi hanya akan diberi butir-butir soal dengan tingkat kesukaran yang tinggi, sedangkan butir-butir soal yang mudah tidak perlu diberikan, begitu sebaliknya, bagi peserta yang berkemampuan rendah hanya akan diberi butir-butir soal dengan tingkat kesukaran rendah, tidak perlu diberikan butir soal yang sukar. Dengan demikian CAT lebih efisien, di samping itu CAT juga lebih reliable, karena kesalahan pengukuran akan lebih kecil disebabkan setiap individu hanya mendapatkan butir soal yang sesuai dengan kemampuannya.

\section{a. Pengertian Tes}

\section{KAJIAN PUSTAKA}

Tes merupakan sejumlah pertanyaan yang memiliki jawaban yang benar atau salah. Tes diartikan juga sebagai sejumlah pertanyaan yang membutuhkan jawaban, atau sejumlah pernyataan yang harus diberikan tanggapan dengan tujuan mengukur tingkat kemampuan seseorang atau mengungkap aspek tetentu dari orang yang dikenai tes (testee). Hasil tes merupakan informasi tentang karakteristik seseorang atau sekelompok orang. Tes merupakan salah satu cara untuk mengestimasi besarnya tingkat kemampuan manusia secara tidak langsung, yaitu melalui respons seseorang terhadap sejumlah stimulus atau pertanyaan. Oleh karena itu agar diperoleh informasi yang akurat dibutuhkan tes yang handal dan sahih.

\section{b. Computerized Testing}

Seiring dengan perkembangan teknologi, pengujian dengan menggunakan komputer mulai dilakukan. Awalnya, komputer hanya digunakan untuk mengotomatisasikan aktivitas pengukuran yang biasa. Tes yang semula berada di kertas dipindahkan ke dalam komputer. Penggunaan komputer seperti ini disebut Computerized Testing atau Computerized-Based Testing (CBT) dan merupakan generasi pertama penggunaan komputer untuk pengujian. Bunderson, Inouye, \& Olsen (1989) dalam Santoso (2010) menyatakan bahwa "beberapa kelebihan dari CBT, yaitu meningkatkan standarisasi, meningkatkan keamanan tes, 
meningkatkan kemampuan tampilan tes, memperkecil error of measurement, serta mempercepat pemberian skor dan interpretasi".

\section{c. Computerized Adaptive Testing}

Computerized Adaptive Testing (CAT) merupakan generasi kedua dari penggunaan komputer untuk pengujian (Bunderson, Inouye, \& Olsen, 1989) dalam Santoso (2010). Adaptive berarti bahwa butir soal yang diberikan disesuaikan dengan tingkat kemampuan setiap peserta tes atau tailored testing (Lord, 1980) dalam Santoso (2010). Pada CAT yang berbasiskan item response theory (IRT), komputer tidak hanya sekedar memindahkan butir soal ke dalam komputer, tetapi komputer diatur untuk menyeleksi dan menyajikan butir soal menurut perkiraan tingkat kemampuan peserta tes. Hal ini mengakibatkan individu peserta tes yang memiliki tingkat kemampuan tinggi akan mendapatkan butir soal yang lebih sulit dibandingkan dengan individu yang memiliki tingkat kemampuan rendah. Sebaliknya individu peserta tes yang memiliki tingkat kemampuan rendah akan mendapatkan butir soal yang lebih mudah dibandingkan dengan individu peserta tes yang memiliki tingkat kemampuan tinggi. Dengan demikian CAT lebih efisien karena dapat mengestimasi kemampuan peserta tes dengan jumlah butir soal yang lebih sedikit dibandingkan P\&P test maupun CBT tanpa mengurangi ketepatan pengukuran (Wainer, 1990; Hambleton, Swaminathan, \& Rogers, 1991; Weiss \& Schleisman, 1999) dalam Santoso (2010).

\section{d. Item Response Theory (IRT)}

Teori tes modern yang berkembang saat ini adalah Item Response Theory (IRT) yang menggunakan beberapa asumsi dasar. Asumsi yang utama adalah peluang seseorang menjawab benar suatu butir tidak ditentukan oleh peluang menjawab benar butir yang lain, dikenal dengan asumsi independen. Teori modern ini berusaha untuk mengembangkan suatu analisis yang menghasilkan estimasi kemampuan seseorang tanpa dipengaruhi alat ukur yang digunakan. Demikian juga statistik butir diusahakan agar tidak tergantung pada karakteristik individu yang diukur.

Asal mula IRT adalah kombinasi suatu versi hukum phigamma dengan suatu analisis faktor butir soal (item factor analysis) kemudian bernama Teori Trait Latent (Latent Trait Theory), sekarang secara umum dikenal menjadi teori jawaban butir soal (Item Response Theory) (McDonald, 1999). Menurut Hambleton, Swaminathan, \& Rogers (1991), teori respons butir (Item Response Theory) didasarkan pada dua buah postulat, yaitu : (a) prestasi subjek pada suatu butir soal dapat diprediksikan dengan seperangkat faktor yang disebut kemampuan laten (latent traits), dan (b) hubungan antara prestasi subjek pada suatu butir dan perangkat kemampuan yang mendasarinya sesuai dengan grafik fungsi naik monoton tertentu, yang disebut kurva karakteristik butir (item characteristic curve, ICC). Kurva karakteristik butir ini menggambarkan bahwa semakin tinggi level kemampuan peserta tes, semakin meningkat pula peluang menjawab benar suatu butir.

\section{e. Tingkat Kesulitan (Difficulty)}

Tingkat kesulitan (difficulty level) suatu butir soal didefenisikan sebagai proporsi atau presentase subjek yang menjawab butir tes tertentu dengan benar. Parameter $b$ mengacu pada titik pada skala kemampuan (ability) di mana seorang peserta mempunyai peluang $50 \%$ menjawal butir soal dengan benar. Semakin besar $b$ semakin sulit butir soal itu. Ketika butir-butir soal diasumsikan mempunyai parameter daya beda (dinyatakan dengan a) yang bervariasi maka model 2P lebih tepat digunakan. Asumsi yang digunakan untuk memperoleh kualitas soal yang baik, khususnya dalam hal tingkat kesukaran soal adalah adanya keseimbangan di samping memenuhi validitas dan reliabilitas. Keseimbangan yang dimaksudkan adalah adanya soal-soal yang termasuk mudah, sedang, dan sukar secara proporsional. Tingkat kesukaran soal dipandang dari kesanggupan atau kemampuan siswa dalam menjawabnya, bukan dilihat dari sudut guru sebagai pembuat soal. Persoalan yang penting dalam melakukan analisis tingkat kesukaran soal adalah penentuan proporsi dan kriteria soal yang termasuk mudah, sedang, dan sukar.

\section{f. Daya Beda (Difference)}

Daya pembeda soal (D) adalah kemampuan suatu soal untuk membedakan antara peserta tes yang pandai (prestasi tinggi) dengan peserta tes yang kurang pandai (prestasi rendah). Suryabrata (1999) dalam Mansyur (2015) menyatakan bahwa "tujuan pokok mencari daya beda ialah untuk menentukan apakah butir soal tersebut memiliki kemampuan membedakan kelompok dalam aspek yang diukur, sesuai dengan perbedaan yang ada pada kelompok tersebut".

Analisis daya pembeda (item discrimination) mengkaji butir-butir soal dengan tujuan untuk mengetahui kesanggupan soal dalam membedakan testee yang tergolong mampu dengan testee yang tergolong kurang mampu. Ansley \& Forsyth (1985) dan Folk \& Green (1989) dalam Santoso (2010) menyarankan bank soal untuk keperluan CAT sebaiknya berisi butir-butir dengan daya beda bersebaran seragam antara 0,4 sampai 2,0.

\section{METODE PENELITIAN}

Penelitian ini merupakan penelitian pengembangan perangkat lunak (software development) sistem tes interaktif berbasis Computerized Adaptive Testing (CAT) pada lembaga Testing Centre Universitas Negeri Makassar. Proses pengembangan dibagi ke dalam beberapa fase diantaranya: Requirement Analysis, Design, Coding, Testing, dan Installation and Maintenance.

Metode perancangan yang digunakan untuk perancangan sistem tes interaktif berbasis CAT ini adalah SDLC (System Development Life Cycle) dengan model waterfall. Software Development Life Cycle (SDLC) dalam rekayasa sistem dan rekayasa perangkat lunak adalah proses pembuatan atau pengubahan sistem serta model dan metodologi yang digunakan untuk mengembangkan sistem. Konsep ini umumnya merujuk pada sistem komputer atau informasi.

Waterfall adalah suatu model pengembangan perangkat lunak yang mengusulkan pendekatan kepada perangkat lunak sistematik dan sekuensial yang mulai pada tingkat kemajuan sistem pada seluruh analisis, design, kode, pengujian dan pemeliharaan. Software Development Life Cycle (SDLC) adalah sebuah proses untuk mengembangkan perangkat lunak. Proses ini dibagi ke dalam beberapa fase diantaranya adalah Requirement Analysis, Design, Coding, Testing, dan Installation and Maintenance. Keseluruhan aktivitas ini akan memberikan tahap yang berbeda sesuai dengan kebutuhan pelanggan. Setiap sistem yang dibangun mengikuti fase ini, baik itu adalah sebuah sistem dengan skala yang kecil ataupun besar (Kumar dkk, 2013).

Sampel penelitian untuk ujicoba program CAT adalah Mahasiswa PPs jurusan PTK Universitas Negeri Makassar. Pengumpulan data dilakukan dengan menggunakan instrumen yang terdiri atas: kuesioner user friendly admin dan kuesioner user friendly testee.

Analisis data dilakukan dengan cara melakukan penilaian pada lembar user friendly untuk masing-masing admin dan testee. Setelah hasil penilaian diperoleh maka data tersebut dianalisis secara statistik deskriptif. Statistik deskriptif adalah statistik yang digunakan untuk menganalisis data dengan cara mendeskripsikan atau menggambarkan data yang telah terkumpul 
sebagaimana adanya. Statistik deskriptif bersifat menjelaskan data dalam ukuran-ukuran nilai angka yang dapat menggambarkan karakteristik data.

\section{HASIL DAN PEMBAHASAN}

Penelitian ini menghasilkan suatu sistem yang bertujuan membantu kinerja lembaga Testing Centre dalam perannya sebagai pusat pengujian berbasis computerized adaptive testing (CAT) yaitu dalam penilaian hasil tes dari peserta yang sebelumnya masih menggunakan tes konvensional jenis Paper and Pencil Testing (P\&P) menjadi tes modern berupa adaptive testing berbasis komputer. Tidak hanya untuk pihak lembaga Testing Centre, sistem ini juga memberikan kemudahan bagi peserta tes dimulai dari proses pendaftaran hingga proses pelaksanaan tes yang jika ditinjau dari sisi sumber daya dan waktu akan lebih hemat, efektif, dan efisien.

Sistem tes yang dikembangkan awalnya diimplementasikan secara lokal menggunakan jaringan Local Area Network (LAN), namun pengembangan lebih lanjut akan dipublikasikan secara online sehingga peserta tidak perlu lagi dibatasi oleh ruang dalam melaksanakan tes. Sistem ini memberikan feedback (timbal balik) pada user testee ketika tes berakhir berupa informasi nilai hasil tes secara langsung.

Algoritma adaptive testing pada penelitian ini didasarkan pada teori respons butir yang asal mulanya adalah kombinasi suatu versi hukum phi-gamma dengan suatu analisis faktor butir soal (item factor analysis) kemudian bernama Teori Trait Latent (Latent Trait Theory), sekarang secara umum dikenal menjadi teori jawaban butir soal (Item Response Theory).

Sistem tes interaktif berbasis computerized adaptive testing (CAT) pada lembaga Testing Centre Universitas Negeri Makassar ini dirancang menggunakan bahasa pemrograman PHP (PHP: Personal Home Page Hypertext Preprocessor) versi 7 dengan metode konekesi database menggunakan PDO (PHP Data Object) yang terdiri dari halaman utama, halaman testee, dan halaman admin dengan jenis database MariaDB. Pada sistem ini juga digunakan framework Javascript yaitu JQuery, framework CSS yaitu Bootstrap, dan Ajax sehingga setiap halaman pada sistem memiliki desain yang responsif dan mudah digunakan.

Berdasarkan hasil dari pengujian black box dan white box maka diperoleh gambaran bahwa setiap use case pada kategori pengujian dapat berfungsi dengan benar dan telah sesuai yang diharapkan. Blackbox testing merupakan pengujian yang mengabaikan mekanisme internal sistem atau komponen dan fokus semata-mata pada output yang dihasilkan yang merespon input yang dipilih dan kondisi eksekusi, sedangkan whitebox testing adalah pengujian yang didasarkan pada pengecekan terhadap detail perancangan, menggunakan struktur kontrol dari desain program secara procedural untuk membagi pengujian ke dalam beberapa kasus pengujian. Dari hasil kedua jenis pengujian tersebut menunjukkan bahwa tidak ada kesalahan yang terjadi pada program.

Selanjutnya, hasil tanggapan responden admin terhadap pengelolaan/administrasi sistem memiliki tanggapan yang sangat baik. Tanggapan dari pengujian user friendly diperoleh dari peserta yang melakukan tes mendapatkan hasil tanggapan berupa kategori sangat baik dan baik pada item pertanyaan yang diberikan. Artinya, admin dan peserta tes (testee) setuju jika sistem interaktif berbasis computerized adaptive testing (CAT) ini diimplementasikan pada lembaga Testing Centre Universitas Negeri Makassar.

Berikut adalah hasil analisis statistik deskriptif tanggapan
Tabel 1 Analisis Statistik Deskriptif Tanggapan Testee

\begin{tabular}{|c|c|c|c|c|c|c|c|c|c|}
\hline \multirow{3}{*}{ No } & \multirow{3}{*}{$\begin{array}{c}\text { Item } \\
\text { Pertany } \\
\text { aan }\end{array}$} & \multicolumn{8}{|c|}{ Tanggapan Responden } \\
\hline & & \multicolumn{2}{|c|}{ SB (4) } & \multicolumn{2}{|c|}{ B (3) } & \multicolumn{2}{|c|}{ C (2) } & \multicolumn{2}{|c|}{$\begin{array}{l}\text { TB } \\
\text { (1) }\end{array}$} \\
\hline & & $\mathbf{f}$ & $\%$ & $\mathbf{f}$ & $\%$ & f & $\%$ & f & $\%$ \\
\hline 1 & item 1 & 17 & 68 & 8 & 32 & 0 & 0 & 0 & 0 \\
\hline 2 & item 2 & 12 & 48 & 12 & 48 & 1 & 4 & 0 & 0 \\
\hline 3 & item 3 & 8 & 32 & 15 & 60 & 2 & 8 & 0 & 0 \\
\hline 4 & item 4 & 20 & 80 & 5 & 20 & 0 & 0 & 0 & 0 \\
\hline 5 & item 5 & 18 & 72 & 6 & 24 & 0 & 0 & 1 & 4 \\
\hline
\end{tabular}

Berdasarkan Tabel 1, dapat dideskripsikan tanggapan responden terhadap item-item variabel aspek user friendly sebagai berikut,

a. Tanggapan responden terhadap pernyataan (item 1) bahwa tampilan sistem menarik, sebagian besar responden menyatakan sangat baik (68\%) dengan skor nilai 92 . Kondisi ini termasuk dalam kategori sangat baik, artinya menurut penilaian user tampilan sistem menarik.

b. Tanggapan responden terhadap pernyataan (item 2) bahwa setiap navigasi atau menu pada sistem mudah dimengerti, jumlah responden menyatakan sangat baik dan baik sama (48\%) dengan skor nilai 86 . Kondisi ini termasuk dalam kategori sangat baik, artinya menurut penilaian user setiap navigasi atau menu pada sistem mudah dimengerti.

c. Tanggapan responden terhadap pernyataan (item 3) bahwa pengaturan dan pemilihan warna pada sistem sangat baik, sebagian besar responden menyatakan baik $(60 \%)$ dengan skor nilai 81. Kondisi ini termasuk dalam kategori baik, artinya menurut penilaian user pengaturan dan pemilihan warna pada sistem sudah baik.

d. Tanggapan responden terhadap pernyataan (item 4) bahwa menu dan navigasi pada sistem berfungsi dengan baik, sebagian besar responden menyatakan sangat baik $(80 \%)$ dengan skor nilai 95. Kondisi ini termasuk dalam kategori sangat baik, artinya menurut penilaian user menu dan navigasi pada sistem berfungsi dengan baik.

e. Tanggapan responden terhadap pernyataan (item 5) bahwa sistem sangat membantu dalam melakukan pelaksanaan tes adaptif berbasis komputer, sebagian besar responden menyatakan sangat baik (72\%) dengan skor nilai 91 . Kondisi ini termasuk dalam kategori sangat baik, artinya menurut penilaian user sistem sangat membantu dalam melakukan pelaksanaan tes adaptif berbasis komputer.

Mengacu dari hasil pada Tabel 1 dapat disimpulkan bahwa skor rata-rata keseluruhan aspek user friendly adalah 89 dengan persentase sebesar $89 \%$ sehingga termasuk kategori sangat baik.

Tabel 2 Analisis Statistik Deskriptif Tanggapan Admin

\begin{tabular}{|c|c|c|c|c|c|c|c|c|c|}
\hline \multirow{3}{*}{ No } & \multirow{3}{*}{$\begin{array}{c}\text { Item } \\
\text { Pertany } \\
\text { aan }\end{array}$} & \multicolumn{8}{|c|}{ Tanggapan Responden } \\
\hline & & \multicolumn{2}{|c|}{ SB (4) } & \multicolumn{2}{|c|}{ B (3) } & \multicolumn{2}{|c|}{ C (2) } & \multicolumn{2}{|c|}{$\begin{array}{l}\text { TB } \\
\text { (1) }\end{array}$} \\
\hline & & f & $\%$ & f & $\%$ & $\mathbf{f}$ & $\%$ & f & $\%$ \\
\hline 1 & item 1 & 4 & 100 & 0 & 0 & 0 & 0 & 0 & 0 \\
\hline 2 & item 2 & 3 & 75 & 1 & 25 & 0 & 0 & 0 & 0 \\
\hline 3 & item 3 & 4 & 100 & 0 & 0 & 0 & 0 & 0 & 0 \\
\hline 4 & item 4 & 2 & 50 & 2 & 50 & 0 & 0 & 0 & 0 \\
\hline 5 & item 5 & 3 & 75 & 1 & 25 & 0 & 0 & 0 & 0 \\
\hline
\end{tabular}


Berdasarkan tabel, dapat dideskripsikan tanggapan responden terhadap item-item variabel aspek user friendly sebagai berikut,

a. Tanggapan responden terhadap pernyataan (item 1) bahwa tampilan sistem menarik, semua responden menyatakan sangat baik $(100 \%)$ dengan skor nilai 16 . Kondisi ini termasuk dalam kategori sangat baik, artinya menurut penilaian admin tampilan sistem menarik.

b. Tanggapan responden terhadap pernyataan (item 2) bahwa setiap navigasi atau menu pada sistem mudah dimengerti, sebagian besar responden menyatakan sangat baik (75\%) dengan skor nilai 15 . Kondisi ini termasuk dalam kategori sangat baik, artinya menurut penilaian admin tampilan sistem menarik.

c. Tanggapan responden terhadap pernyataan (item 3) bahwa menu dan navigasi pada sistem berfungsi dengan baik, semua responden menyatakan sangat baik $(100 \%)$ dengan skor nilai 16. Kondisi ini termasuk dalam kategori sangat baik, artinya menurut penilaian admin menu dan navigasi sistem berfungsi dengan baik.

d. Tanggapan responden terhadap pernyataan (item 4) bahwa sistem membantu dalam memberikan pelaporan hasil tes, jumlah responden menyatakan sangat baik dan baik sama (50\%) dengan skor nilai 14 . Kondisi ini termasuk dalam kategori sangat baik, artinya menurut penilaian admin sistem membantu dalam memberikan pelaporan hasil tes.

e. Tanggapan responden terhadap pernyataan (item 5) bahwa sistem sangat membantu dalam administrasi pelaksanaan tes, sebagian besar responden menyatakan sangat baik (75\%) dengan skor nilai 15 . Kondisi ini termasuk dalam kategori sangat baik, artinya menurut penilaian admin sistem sangat membantu dalam administrasi pelaksanaan tes.

Mengacu dari hasil pada Tabel 2 dapat disimpulkan bahwa skor rata-rata keseluruhan aspek user friendly admin adalah 15,2 dengan persentase sebesar 95\% sehingga termasuk ke dalam kategori sangat baik.

Adapun hasil simulasi tes pada sistem computerized adaptive testing ini dapat dilihat pada Tabel 3.

\begin{tabular}{|c|c|c|r|r|r|r|r|}
\hline No & Id & $\mathbf{u}_{i}$ & \multicolumn{1}{c|}{ b } & \multicolumn{1}{c|}{$\mathbf{a}$} & \multicolumn{1}{c|}{$\boldsymbol{\theta}$} & \multicolumn{1}{c|}{$\mathbf{I}(\boldsymbol{\theta})$} & \multicolumn{1}{c|}{ SE } \\
\hline 1 & 104 & 0 & -3 & 0,6 & -3 & 0,25 & 2 \\
\hline 2 & 109 & 0 & $-2,74$ & 0,7 & -3 & 0,49 & 1,42 \\
\hline 3 & 73 & 0 & $-2,65$ & 1,48 & -3 & 0,70 & 1,19 \\
\hline 4 & 86 & 1 & $-2,8$ & 1,3 & $-2,8$ & 0,93 & 1,03 \\
\hline 5 & 126 & 1 & $-2,42$ & 1,36 & $-2,42$ & 1,14 & 0,93 \\
\hline 6 & 96 & 1 & $-1,9$ & 0,72 & $-1,9$ & 1,37 & 0,85 \\
\hline 7 & 107 & 0 & $-1,21$ & 0,62 & $-1,9$ & 1,59 & 0,79 \\
\hline 8 & 88 & 1 & $-1,04$ & 0,56 & $-1,04$ & 1,80 & 0,74 \\
\hline 9 & 125 & 1 & $-0,52$ & 0,87 & $-0,52$ & 2,02 & 0,70 \\
\hline 10 & 66 & 1 & $-0,34$ & 1,19 & $-0,34$ & 2,26 & 0,66 \\
\hline 11 & 134 & 1 & 0,24 & 0,4 & 0,24 & 2,50 & 0,63 \\
\hline 12 & 106 & 0 & 0,75 & 2 & 0,24 & 2,63 & 0,61 \\
\hline 13 & 72 & 1 & 0,89 & 1,76 & 0,89 & 2,74 & 0,60 \\
\hline 14 & 81 & 0 & 1,11 & 0,4 & 0,89 & 2,98 & 0,57 \\
\hline 15 & 75 & 1 & 1,31 & 0,4 & 1,31 & 3,23 & 0,55 \\
\hline
\end{tabular}

\begin{tabular}{|r|c|c|r|r|r|r|r|}
\hline 16 & 137 & 1 & 1,91 & 0,4 & 1,91 & 3,47 & 0,53 \\
\hline 17 & 89 & 0 & 2,25 & 0,89 & 1,91 & 3,70 & 0,51 \\
\hline 18 & 91 & 0 & 2,28 & 0,4 & 1,91 & 3,95 & 0,50 \\
\hline 19 & 119 & 1 & 2,17 & 1,5 & 2,17 & 4,17 & 0,48 \\
\hline 20 & 121 & 0 & 2,89 & 0,4 & 2,17 & 4,41 & 0,47 \\
\hline 21 & 117 & 0 & 2,58 & 0,74 & 2,17 & 4,64 & 0,46 \\
\hline 22 & 128 & 0 & 2,51 & 0,4 & 2,17 & 4,89 & 0,45 \\
\hline 23 & 120 & 1 & 2,68 & 0,4 & 2,68 & 5,13 & 0,44 \\
\hline 24 & 139 & 0 & 3 & 0,52 & 2,68 & 5,38 & 0,43 \\
\hline 25 & 138 & 1 & 3 & 0,64 & 3 & 5,62 & 0,42 \\
\hline
\end{tabular}

Berdasarkan hasil pada Tabel 3, estimasi kemampuan peserta tes dalam CAT dilakukan berdasarkan teori respons butir. Mula-mula peserta tes diberi soal dengan tingkat kesulitan awal yang mudah (b awal $=-3$ ) karena dianggap mempunyai tingkat kemampuan awalnya $(\theta$ awal) rendah $(\theta$ awal $=-3)$. Peserta tes diberi kesempatan untuk menjawab soal dengan alokasi waktu tertentu.

Jika soal dengan tingkat kesulitan mudah tersebut dapat dijawab benar, peserta diberi soal baru yang lebih sulit, jika dijawab salah maka peserta diberi soal yang setara mudah. Kemudian kemampuan $(\theta)$ setelah menjawab soal, $\mathrm{P}(\theta), \mathrm{Q}(\theta), \mathrm{I}_{i}(\theta)$, $\operatorname{SE}(\theta)$, dan harga mutlak selisih kesalahan baku antar penyajian soal dihitung. Proses ini dilakukan sampai stopping rule tercapai, kemudian kemampuan $(\theta)$ akhir peserta tes dihitung.

Rumus yang digunakan untuk menghitung kemampuan $(\theta)$, probabilitas menjawab benar berdasarkan kemampuan tersebut $(P(\theta))$, probabilitas menjawab salah $(\mathrm{Q}(\theta))$, fungsi informasi butir $\left(I_{i}(\theta)\right)$, dan kesalahan baku $(S E(\theta)$ adalah sebagai berikut (Birnbaum dalam Hambleton, Swaminathan \& Rogers, 1991; Baker, 2001).

$$
\begin{gathered}
\theta=b_{i}+\frac{1}{D a_{i}} \ln \left(0 . 5 \left(1+\sqrt{\left(1+8 c_{i}\right)}\right.\right. \\
\text { di mana } c=0(2 P L) \\
P_{i}(\theta)=\frac{e^{D a_{i}\left(\theta-b_{i}\right)}}{1+e^{D a_{i}\left(\theta-b_{i}\right)}} \\
Q_{i}(\theta)=1-P_{i}(\theta) \\
I_{i}(\theta)=P_{i}(\theta) Q_{i}(\theta) \\
S E(\theta)=\frac{1}{\sqrt{\sum_{i=1}^{N} I_{i}(\theta)}}
\end{gathered}
$$

Terdapat aturan pemberhentian (stopping rule) dalam sistem CAT. Aturan yang digunakan ada empat yaitu sebagai berikut,

a. Jika butir soal habis

Jika soal habis dan peserta tes pernah menjawab soal dengan benar, maka kemampuan $(\theta)$ akhir peserta tes adalah kemampuan tertinggi yang pernah dicapainya. Jika soal habis dan peserta tes belum pernah menjawab soal dengan benar, maka kemampuan $(\theta)$ akhir peserta tes kemampuan terendah yang dihitung berdasarkan butir soal yang memiliki indeks kesulitan paling rendah. 
b. Jika waktu berakhir

Dalam pelaksanaan tes sistem CAT ini, telah ditetapkan interval waktu pengerjaan sehingga jika waktu berakhir maka tes akan dihentikan.

c. Jika telah menjawab salah sebanyak yang telah ditentukan

Tes akan dihentikan dan memberikan hasil akhir estimasi kemampuan testee jika testee telah menjawab pertanyaan dengan jawaban salah sebanyak empat kali secara berturutturut.

d. Jika estimasi kesalahan baku pengukuran mencapai 0,30

Kesalahan baku pengukuran sebesar 0,30 setara dengan reliabilitas sebesar $91 \%$ pada tes konvensional.

Berdasarkan Tabel 3, mula-mula sistem memberikan soal mudah pada testee dengan memunculkan soal dengan id 104. Karena dijawab salah, maka sistem akan kembali memunculkan soal yang mudah dengan id 109. Pada soal ke-empat karena dijawab benar, maka pada soal selanjutnya akan diberikan soal dengan tingkat kesulitan yang lebih tinggi. Pemilihan butir soal didasarkan pada kriteria step size sebesar 0,5 sehingga soal berikutnya dipilih berada pada rentang lebih besar 0,5 dari tingkat kesulitan soal sebelumnya. Sistem akan terus bekerja hingga kondisi stopping rule tercapai.

\section{KESIMPULAN}

Sistem yang dirancang merupakan sebuah sistem yang dapat digunakan untuk melakukan pelaksanaan tes adaptif berbasis komputer dengan tujuan memberikan hasil tes yang lebih akurat dan lebih efisien jika dibandingkan dengan jenis tes CBT biasa.

Berdasarkan hasil tanggapan responden admin terhadap kemudahan administrasi/ pengelolaan sistem, diperloeh persentase nilai skor akhir rata-rata sebesar $95 \%$ artinya berada pada kategori sangat baik. Kemudian pada tanggapan aspek user friendly dari peserta tes (testee) diperoleh skor persentase nilai akhir rata-rata sebesar $89 \%$ artinya berada pada kategori sangat baik, sehingga dapat disimpulkan bahwa sistem tes interaktif berbasis computerized adaptive testing (CAT) ini mudah dikelola oleh admin dan mudah digunakan oleh peserta tes (testee).

Sistem ini mengacu pada teori respons butir dengan dua parameter logistik (2PL) sehingga dalam alur algoritmanya mengacu pada dua hal yaitu tingkat kesulitan (parameter $b$ ) dan daya beda (parameter $a$ ).

\section{DAFTAR PUSTAKA}

[1] Allen, M.J. \& Yen, W.M. (1979). Introductions to measurement theory, Belmont, CA: Wadsworth, Inc.

[2] Andre. 2014. Tutorial Belajar PHP Part 1: Pengertian dan Fungsi PHP dalam Pemrograman Web, (on line), (http://www.duniailkom.com/pengertian- dan-fungsi-phpdalam-pemograman-web/, diakses 30 Oktober 2020).

[3] Azmi, Fauzan. 2007. Web Server, (on line), (http://blog.azmifauzan.net/wp-

content/uploads/2007/10/web-server.pdf, diakses Oktober 2020).

[4] Bin Ladjamudin, Al Bahra. 2005. Analisis dan esain sistem informasi. Yogyakarta:Graha Ilmu.

[5] Dwiartara, Loka. 2010. Menyelam dan Menaklukkan Samudra PHP. Bogor:Ilmu Website.

[6] Fatta, Hanif Al. 2007. Analisis dan Perancangan Sistem Informasi untuk Keunggulan Bersaing Perusahaan dan Organisasi Modern. Yogyakarta : Andi

[7] Kumar, Naresh, Zadgaonkar, A. S., Shukla, Abhinav. 2013. Evolving a New Software Development Life Cycle Model SDLC-2013 with Client Satisfaction. 3 (1): 216-221

[8] Mansyur, Rasyid, Harun, Suratno. 2015. Asesmen Pembelajaran di Sekolah. Yogyakarta: Pustaka Belajar.
[9] Mardapi, Djemari, Haryanto, Hadi, Samsul. 2012. Pengembangan Sistem Pengujian Hasil Belajar Berbantuan Komputer (Computerized Adaptive Testing), (on line), (http://eprints.uny.ac.id/24204/, diakses 30 Oktober 2020)

[10] McDonald R.P. 1999. Test Theory: A Unified Treatment. New Jersey:Larvrence Erbaum Associates Publishers.

[11] Mills, C.N. (1999). Development and introduction of a computere adaptive graduate record examinations general test. Dalam F. Drasgow \& J. B. Olson-Buchanan (Eds), Innovations in Computerized Assessment (pp. 117-136). Mahwah, NJ: Lawrence Erlbaum Associates Publishers.

[12] Myers. 2004. Pengujian Sakti: Strategi dan Metode, (on line), (www.span.depkeu.go.id/ content/pengujian-saktistrategi-dan-metode, diakses 30 Oktober 2020).

[13] Nugroho, Bunafit. 2013. Dasar Pemrograman Web PHP-MySQL dengan Dengan Dreamweaver. Yogyakarta: Gava Media.

[14] Santoso, Agus, Astuti, Dwi, Unggul Utan, dkk. 2010. Pengembangan Model Sistem Ujian Berdasarkan Computerized Adaptive Testing sebagai Upaya Efisiensi Penyelenggaraan Ujian Universitas Terbuka. Skripsi. Universitas Terbuka, (on line), (http://www.pustaka.ut.ac.id/ pdfpenelitian/81865.pdf, diakses 30 Oktober 2020).

[15] Wainer, H. (1990). Computerized adaptive testing: A primer (2nd ed.). Hillsdale, NJ: Lawrence Erlbaum Associates. 